\title{
Mitochondrial disease: genetics and management
}

\author{
Yi Shiau $\mathrm{Ng}^{1} \cdot$ Doug M. Turnbull ${ }^{1}$
}

Received: 25 June 2015/Revised: 18 August 2015/Accepted: 18 August 2015/Published online: 28 August 2015

(C) The Author(s) 2015. This article is published with open access at Springerlink.com

\begin{abstract}
Mitochondrial disease is one of the most common groups of genetic diseases with a minimum prevalence of greater than 1 in 5000 in adults. Whilst multi-system involvement is often evident, neurological manifestation is the principal presentation in most cases. The multiple clinical phenotypes and the involvement of both the mitochondrial and nuclear genome make mitochondrial disease particularly challenging for the clinician. In this review article we cover mitochondrial genetics and common neurological presentations associated with adult mitochondrial disease. In addition, specific and supportive treatments are discussed.
\end{abstract}

Keywords Mitochondrial disease - Mitochondrial DNA $($ mtDNA $) \cdot$ Nuclear genes $\cdot$ Acute and chronic neurological presentations - Treatment

\section{Introduction}

Mitochondrial disease is a collective term that encompasses the genetically and clinically heterogeneous group of diseases due to defects in mitochondrial oxidative phosphorylation. It is one of the most common groups of genetic disease and can be caused by mutation in either mitochondrial DNA or nuclear genes that directly or indirectly interfere with the mitochondrial respiratory chain function. To date, mitochondrial proteomics analysis

Doug M. Turnbull

doug.turnbull@ncl.ac.uk

1 Wellcome Trust Centre for Mitochondrial Research, Institute of Neuroscience, The Medical School, Newcastle University, Framlington Place, Newcastle upon Tyne NE2 4HH, UK reveals that in addition to the 13 proteins encoded by the mitochondrial genome, around 1500 proteins [50] are linked to various mitochondrial functions and so far more than 200 genes have been implicated in the development of human disease [40].

A number of syndromes have been described in mitochondrial disease but often patients present with non-syndromic presentation of which nervous system is most commonly affected [49]. In addition to the diagnostic challenge, clinicians also encounter difficulty in the management of mitochondrial disease due to lacking of effective disease-modifying therapy and, until recently, best practice guidelines on various complications associated with the disease [59].

In this review article, we discuss the genetics and epidemiology of mitochondrial disease, neurological presentations and their management, genetic counselling and reproductive options for patients.

\section{Mitochondrial genetics}

Mitochondria are cellular organelles found in all nucleated human cells. A crucial function of mitochondria is to generate energy in the form of ATP (adenosine triphosphate) via oxidative phosphorylation using predominantly carbohydrates and fatty acids as fuel. The oxidative phosphorylation system (OXPHOS) is located in the inner membrane and it consists of five multimeric protein complexes: complex I-IV form the respiratory chain and complex V (ATP synthase). In addition, there are two mobile electron carriers (co-enzyme Q10 and cytochrome $c$ ).

Mitochondria are under dual genetic control of the mitochondrial and nuclear genomes. The mitochondrial genome consists of multiple copies of $16,569 \mathrm{bp}$, double 
stranded mitochondrial DNA (mtDNA) molecules and located adjacent to the OXPHOS system in the matrix. Only thirty-seven genes ( 22 transfer RNAs, 2 ribosomal RNAs and 13 polypeptides that form structural subunits of OXPHOS system) [86] are encoded by mtDNA. The remaining mitochondrial proteins, including the majority of respiratory chain subunits (79 out of 92 ), assembly factors of the respiratory chain, those involved in maintenance and expression of mtDNA, mtDNA transcription and translation, and control the mitochondrial dynamics are nuclear encoded [16], synthesised in the cytosol and imported to the mitochondria [51].

There are several unique properties associated with the mitochondrial genome that are important in understanding the primary mitochondrial DNA disease: (1) there are multiple copies (up to thousands) of mtDNA in each cell; (2) mtDNA is maternally inherited; (3) the phenomenon of homoplasmy and heteroplasmy. Homoplasmy implies all mtDNA are identical which could be all wild type or mutated. Heteroplasmy is a mixture of mutated and wild type mtDNA. In the presence of heteroplasmy there is a threshold effect and clinical expression can vary between different tissues and mtDNA mutations. In women with heteroplasmic mtDNA mutations there is a bottleneck in the female germline which means that the transmission of heteroplasmy level from mother to offspring is often random and unpredictable. This explains the heterogeneity in heteroplasmy level, clinical phenotype and severity frequently observed within the same pedigree.

Multiple mtDNA deletions and mtDNA depletion (reduced copy number of mtDNA) are secondary changes in mtDNA due to mutations in the mtDNA replication and/or maintenance genes such as POLG, PEO1, ANT1, DGUOK, TYMP [72]. Mitochondrial depletion syndrome is associated with infantile/early childhood onset, multi-system disease with fatal outcome and multiple deletions generally result in later onset (child- or adulthood) and milder disease burden.

The emergence of next generation sequencing is leading to rapid discovery of new nuclear genes linked to mitochondrial disease and the classification of nuclear gene related mitochondrial disease is summarised in Table 1. There is also increased recognition of mitochondrial dysfunction and genetic mutation in various other genetic neurological disorders, for examples SPG7 gene in hereditary spastic paraplegia [58] and ataxia [61] and GDAP1 gene in Charcot-Marie-Tooth disease type 4A $[56,96]$.

The inheritance pattern of mitochondrial disease is dependent on the genetic mutations. Point mutations in the primary mitochondrial DNA such as m.3243A $>\mathrm{G}$, three common LHON mutations, m.8344A $>$ G, m.8993T $>$ G/C, m.1555A $>\mathrm{G}$ and others are maternally inherited but sporadic mutations exist [53]. Single, large deletions in mtDNA are a common cause mitochondrial disease and they occur sporadically with rare exceptions [15]. The inheritance patterns of mutations in nuclear genes causing mitochondrial disease include autosomal recessive, dominant or X-linked. Both recessive and dominant forms exist in several mtDNA maintenance genes, for examples $P O L G, P E O 1$ and RRM2B genes.

\section{Epidemiology of mitochondrial disease}

The overall prevalence of mitochondrial disease is comparable to other neurogenetic diseases such as CharcotMarie-Tooth (CMT) disease, myotonic dystrophy and muscular dystrophy. The prevalence of adult mitochondrial disease, both affected patients and those at risk, has recently been reported to be approximately 1 in 4300 in North East England [28]. Primary mutations in the mtDNA are more prevalent in the adult patients compared to mutations in the nuclear genes, and vice versa in the paediatric population where there is a much higher incidence of autosomal recessive disease particularly in consanguineous families. Although several hundreds of mutations have been reported in mtDNA since 1988, a handful of mutations are far more common than the others, for examples m.1555A $>\mathrm{G}$ (associated with aminoglycoside induced deafness), m.3243A $>\mathrm{G}$ (associated with MELAS syndrome and MIDD), m.3460G $>A$ and m.11778A $>$ G (associated with LHON), have an estimated prevalence of $0.19,0.14,0.11$ and $0.11 \%$, respectively, in the population $[11,21]$. However, individuals with these common mutations may remain clinically asymptomatic throughout their life if not exposed to relevant toxin or if they have a low mutation load.

\section{Clinical diagnosis}

Mitochondria are ubiquitous and therefore mitochondrial disease can affect any organ, although organs with high energy demand such as brain, skeletal muscle and heart, are more commonly affected than the others. The clinical features are heterogeneous and often can mimic many neurological or other systemic diseases. Multi-system involvement is often evident with detailed clinical examination and investigations in most cases although there are exceptions such as Leber hereditary optic neuropathy (LHON). Paediatric onset disease is associated with more severe multi-systemic involvement, relentless progression and poorer prognosis, however, there are rare exceptions such as reversible respiratory chain deficiency caused by the m.14674T $>$ C mutation [33]. 


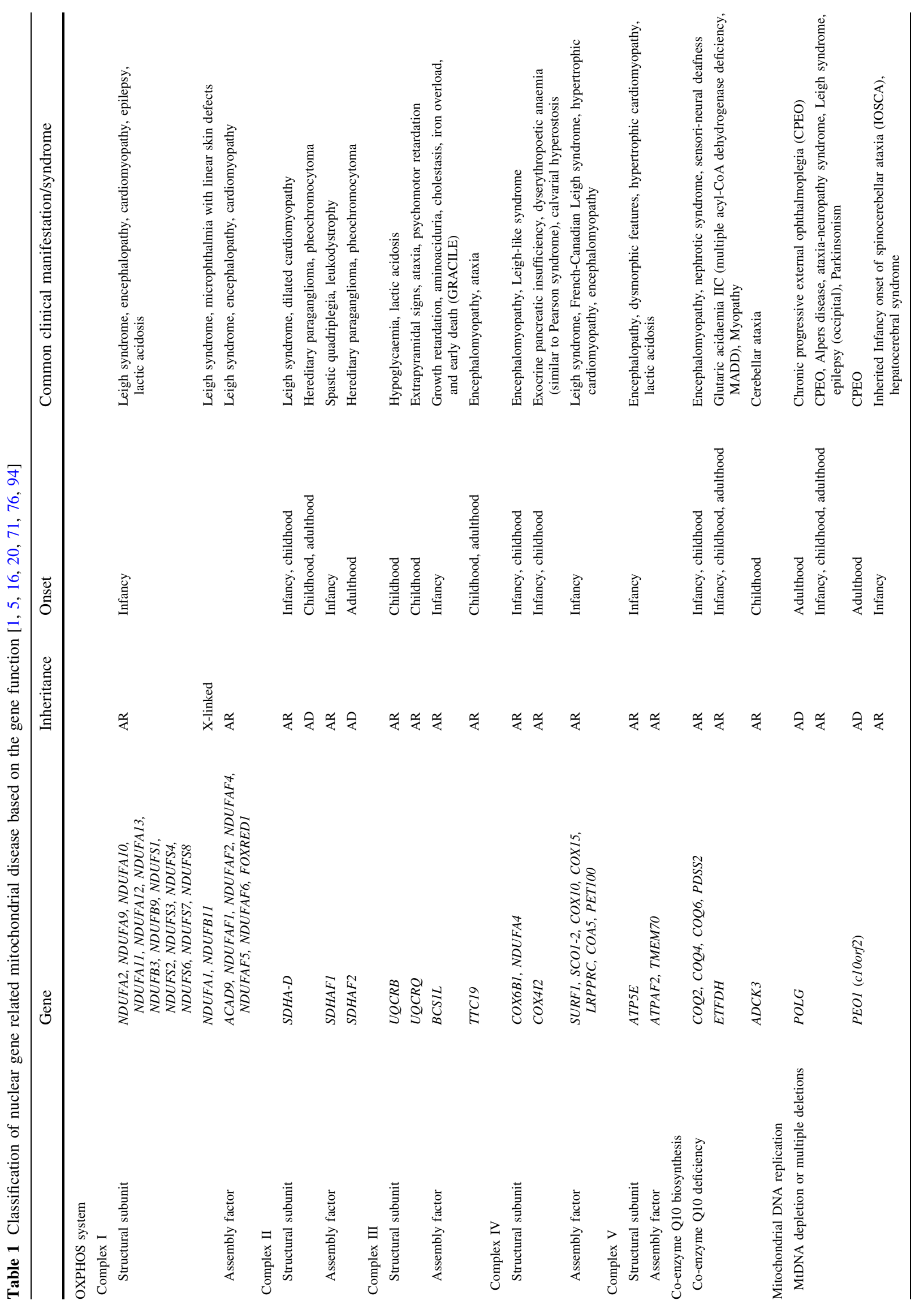







Many classic syndromes have been described over the last few decades. The examples of clinical syndromes associated with adolescence and adulthood include mitochondrial encephalomyopathy, lactic acidosis with strokelike episode (MELAS), myoclonic epilepsy with ragged red fibres (MERRF), mitochondrial neuro-gastrointestinal involvement and encephalopathy (MNGIE), neuropathy, ataxia and retinitis pigmentosa (NARP), chronic progressive external ophthalmoplegia (CPEO). In contrast, syndromes with neonatal and childhood onset include Alpers disease, Pearson syndrome, Leigh disease, Sengers syndrome and Kearns-Sayre syndrome.

However, clinicians are more commonly confronted by the non-specific constellation of clinical features. Many symptoms associated with mitochondrial disease such as deafness, diabetes, myopathy, gastrointestinal symptoms and others are also common on their own in the population but the 'unusual' combination of these symptoms in the same individual should alert the clinicians about the possibility of mitochondrial disease. Detailed system-based examination coupled with extended investigations is necessary to identify other system involvement such as short stature, sensori-neural deafness, pigmentary retinopathy, optic atrophy, diabetes mellitus and/or other endocrine dysfunction, cardiac involvement, renal tubulopathy and others. This systemic involvement may be subtle and asymptomatic in the early phase of disease. Disease rating scales have been utilised to document the extent of system involvement, disease burden and progression in paediatric and adult patients [62, 69].

Family history can be informative and often reveals what appear to be seemingly unrelated diseases among the maternal family members in primary mtDNA disease and the m.3243A $>\mathrm{G}$ mutation is a prime example [54]. It is important to ascertain history of consanguinity when recessive disease is suspected. Late adulthood presentation and/or lacking of apparent family history should not deter testing for mitochondrial disease because sporadic mutations or late presenting autosomal dominant diseases are not uncommon.

\section{Acute neurological presentations}

\section{Stroke-like episodes and acute symptomatic seizure}

MELAS syndrome is a severe, multi-system disease characterised by recurrent metabolic strokes with typical onset of below 40 years [31] although patients at the older age have been reported [6,92]. Headache and prominent visual disturbance (both positive and negative symptoms) are often the prodrome of acute stroke-like episodes and can occur days or weeks before the development of focal 
Fig. 1 Axial FLAIR (a, b) and DWI $(\mathbf{c}, \mathbf{d})$ sequences of MRI head. $\mathbf{a}$ and $\mathbf{c}$ were performed on admission whilst $\mathbf{b}$ and d were performed 8 days later. The stroke-like lesion 'spread' from the right occipital lobe to the right temporal lobe and thalamus
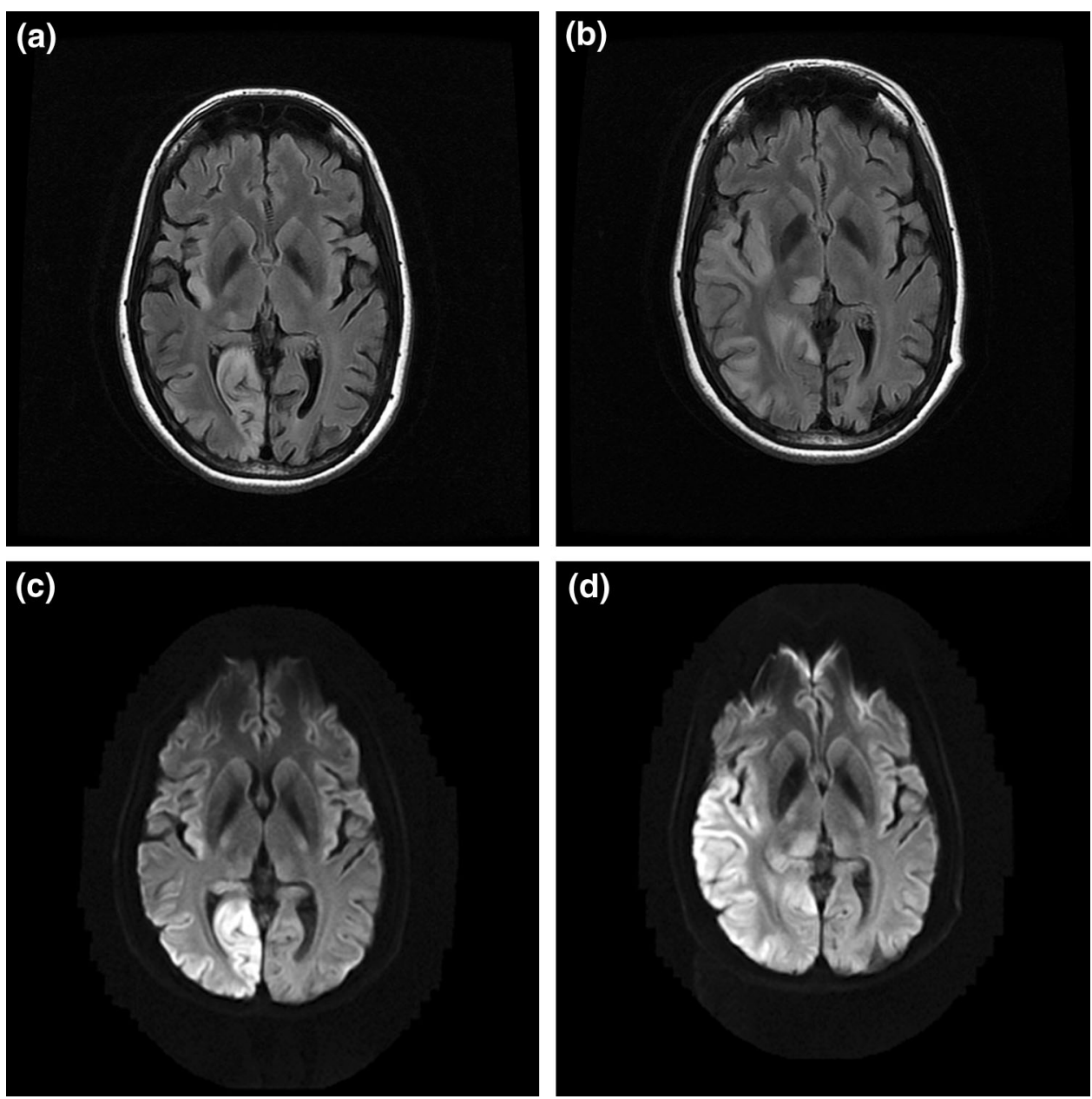

neurological deficit or motor seizure. These visual symptoms can masquerade as migranous visual aura but in fact is the onset of occipital seizure [24, 35]. The severity of neurological deficits are related to the extent of parietal, temporal and occipital lobe involvement such as dysphasia, dyspraxia, heminanopia, cortical blindness, mild hemiparesis and psychosis. Epilepsia partialis continua and less commonly generalised status epilepticus occur during the stroke-like episodes in some patients.

The key imaging findings are cortical and subcortical lesions that cross the vascular territories of middle cerebral artery and posterior cerebral arteries and bilateral, asymmetrical changes are not infrequent (Fig. 1). The most common cause of MELAS phenotype is $\mathrm{m} .3243 \mathrm{~A}>\mathrm{G}$ mutation which accounts for $80 \%$ of cases but mutations in the nuclear gene $P O L G$, encoding for the catalytic subunit of DNA polymerase $\gamma$ (pol $\gamma$ ), can cause similar stroke-like lesions [14, 19]. However, the $P O L G$-related disease often has more aggressive disease course with explosive onset of focal seizure and status epilepticus that is highly refractory to pharmacological treatments in children and young adults and the outcome is very poor.
Administration of sodium valproate is recognised to trigger fulminant hepatic failure among patients with POLG disease $[73,80]$. In contrast, patients who have stroke-like episodes associated with the m.3243A $>\mathrm{G}$ mutation tend to have pre-existing, and often subtle, multi-system involvement and they often make good recovery in conjunction with the partial or complete resolution of imaging changes within few weeks or months at the early course of disease if appropriately managed (refer to Treatment section). Nevertheless, recurrence of stroke-like episodes leads to cumulative neuronal loss and results in severe cognitive impairment.

Given the high prevalence of $\mathrm{m} .3243 \mathrm{~A}>\mathrm{G}$ mutation and common carrier status of several pathogenic variants in POLG gene (p. A467T, p. W748S and p. G848S) in populations of European descent [29], clinicians should prioritise mitochondrial disease as a main differential diagnosis to atypical, evolving posterior circulation stroke, recurrent 'encephalitis/encephalopathy' with negative infective screen, auto-antibodies and 'atypical/recurrent' posterior reversible encephalopathy syndrome (PRES). Securing the diagnosis of mitochondrial disease early can 
avert the patients having invasive diagnostic procedure such as brain biopsy or potentially harmful treatment such as immune-suppressants.

\section{Subacute visual loss}

The classic presentation of LHON is subacute, evolving painless visual loss in young adults with male predominance $(4: 1)$ [43]. Majority of the cases have the contralateral eye affected within a year and visual loss is often irreversible. Although there is a conventional belief that LHON mutations only affect eyes, other neurological features such as dystonia [48], myoclonus [41], sensori-neural deafness [66] may occur which broaden the spectrum of the clinical phenotype in these mutations [48]. It is clear that therefore LHON should be considered as a differential diagnosis to the 'atypical' optical neuritis that shows no recovery and Susac's syndrome [97]. A link between LHON mutations and multiple sclerosis was speculated for a long time and a recent study has suggested that such association may occur by chance even though mechanistic interaction is possible [57].

Dominant optic neuropathy is caused by mutations in the nuclear gene such as OPAl and the irreversible visual loss often occurs in the childhood [95] although late-onset optic neuropathy after 4th decade [2] and adult-onset CPEO and parkinsonism with subclinical optic neuropathy have recently been described [12].

\section{Chronic neurological presentations}

\section{Chronic progressive external ophthalmoplegia and ptosis}

More than half of adult patients have external ophthalmoplegia and/or ptosis in our large cohort of patients (unpublished). Ptosis and ophthamoplegia can be asymmetrical at the outset but most cases become symmetrical with time. CPEO is one of the main presenting features in adult patients with mitochondrial disease [77] and ptosis often imposes more functional limitation than the restricted eye movement because the extra-ocular paresis occurs insidiously allowing cerebral adaptation and symptomatic diplopia is less common. Some patients with CPEO phenotype are occasionally misdiagnosed as other conditions such as seronegative myasthenia gravis.

\section{Myopathy}

Many adult patients experience fatigue, exercise intolerance and muscle weakness. The degree of proximal myopathy is often mild on clinical testing and it progresses slowly. Early loss of ambulation due to muscle weakness is not a typical feature of adult mitochondrial disease with a few exceptions such as patients with Kearns-Sayre syndrome caused by single deletion in mtDNA and TK2 mutation [4]. There is a risk of aspiration when facial and oropharyngeal weakness is present in addition to the respiratory muscle weakness. Some patients may have normal muscle strength and EMG study but complain of limited exercise capacity with recurrent nausea and/or vomiting on exertion due to lactic acidosis.

\section{Ataxia}

Cerebellar ataxia is often subtle at the onset and typically progress with time and becomes debilitating in many genotypes. Cerebellar atrophy is a common imaging finding. Sensory ataxia due to dorsal root ganglionopathy is one of the defining features in SANDO phenotype (sensory ataxia, neuropathy, dysarthria and ophthalmoplegia) caused by $P O L G$ mutations [42].

\section{Neuropathy}

Diminished or absent long tendon reflexes are a common clinical finding and axonal neuropathy is the most common finding in nerve conduction studies in adult patients with mitochondrial disease with a few exceptions such as demyelinating neuropathy described in patients with MNGIE [25]. A recent study showed that neuropathy is a useful feature to guide molecular diagnosis in adult patients with CPEO [32].

\section{Diagnostic approach}

Comprehensive diagnostic criteria and guidelines have been published to provide a framework for clinicians when investigating patients with suspected mitochondrial disease $[8,85,86]$. Patients who present with classic syndromes such as MELAS, MERRF, LHON and Alpers disease can be diagnosed by direct sequencing of mitochondrial genes or POLG gene in blood. It is important to consider that blood heteroplasmy (leucocytes) declines with age in m.3243A $>$ G [65] and 'false negative result' is possible in older adults therefore concomitant testing of additional tissue such as urinary epithelium is recommended. Some nuclear gene mutations have been found to have association with distinctive radiological appearances which can expedite the candidate gene sequencing, these include leukoencephalopathy with brainstem and spinal cord involvement and lactate elevation (LBSL) caused by DARS2 mutations [89] and leukoencephalopathy with thalamus and brainstem involvement and high lactate (LTBL) caused by EARS2 mutations [78]. 
However, many mitochondrial diseases do not have pathognomonic features that point towards a particular genetic diagnosis and muscle biopsy remains important in current clinical practice. The findings of muscle biopsy that are supportive of mitochondrial disease include: ragged red fibres (RRF), COX-negative fibres, individual complex or multiple respiratory chain deficiency, qualitative (multiple deletions) and quantitative (depletion) abnormalities in mtDNA.

Next generation sequencing is a new and highthroughput technique that allows sequencing of multiple candidate genes simultaneously leading to a more rapid diagnosis and increase the diagnostic yield [88] especially in the well-phenotyped cohort of patients [84]. Clinical exome sequencing is likely to become part of standard clinical care for undiagnosed patients.

\section{Treatment and long term management}

\section{Specific treatment in mitochondrial disease}

Currently, there remains no effective and specific treatment for vast majority of patients with mitochondrial disease. Various treatments (mostly nutritional supplements) such as co-enzyme Q10, carnitine, creatine, dichloroacetate and vitamin 'cocktails' have been widely used based upon anecdotal data and individual case reports, however, Cochrane systemic review of treatments that were tested in randomised-control trials concluded that none of these treatment showed meaningful clinical efficacy [59]. Since then, another randomised, controlled trial using idebenone in LHON mutations found no significant result in the primary end point defined as the best recovery in visual acuity but post hoc interaction analysis suggested benefits in those with discordant visual acuities [38]. EPI-743, a novel antioxidant has been reported to show clinical improvement in small number of patients with Leigh syndrome [47] and LHON [67] in the open-label clinical trials and phase 2B randomized-control trial is currently in progress.

Although there is no formal clinical trial, supplement of high dose co-enzyme Q10 (up to $2400 \mathrm{mg}$ in three divided doses in adults; $30 \mathrm{mg} / \mathrm{kg}$ in paediatric cases) in primary co-enzyme Q10 biosynthetic defect has been reported to show variable clinical improvement across different phenotypes [23].

L-arginine has been reported to be effective in treating acute stroke-like episodes associated with m.3243A $>$ G mutation [39]. However, this result is yet to be replicated by other research groups.

Allogenic haematopoietic stem cell transplant has emerged as a promising therapeutics to restore the enzymatic function in patients with MNGIE caused by TYMP mutations but this treatment is associated with high morbidity and mortality $[25,75]$.

\section{Supportive treatment and surveillance for complications}

Symptomatic treatment and screening for associated complications remain fundamental to the management of mitochondrial disease.

\section{Acute seizure and stroke-like episodes}

Early recognition and prompt, aggressive seizure management are crucial to mitigate the cellular metabolic crisis perpetuated by the ictal activities [10]. The seizure management should follow the guidelines on status epilepticus except sodium valproate is absolutely contra-indicated in $P O L G$ mutations. Phenytoin was implicated in causing paralytic ileus in a patient with stroke-like episodes [17], however, this is likely to be a co-incidental finding as pseudo-obstruction is a common complication associated with MELAS syndrome [74] and we use this drug regularly to control seizures. Anecdotal evidence on the use of magnesium infusion [91], ketamine [64], ketogenic diet $[34,46,79]$, folinic acid supplement [30] in termination of status epilepticus associated with $P O L G$ and m.3243A $>\mathrm{G}$ has been reported.

\section{Pseudo-obstruction}

Several genetic mutations (TYMP, m.3243A $>\mathrm{G}$ and $P O L G)$ have been associated with intestinal pseudo-obstruction [9, 63, 83, 90] involving small and/or large intestine. Distinguishing this from mechanical obstruction is of paramount importance as they tend to resolve with conservative management alone and surgery has little role and could exacerbate the metabolic crisis. Serum lactate is not a reliable marker for tissue ischaemia in patients with mitochondrial disease because some patients have persistently raised lactate even when they are well. Aggressive medical management of acute episodes is important as is prevention by using regular laxatives.

\section{Cardiac involvement}

Cardiac involvement is often part of the multi-system manifestation in adult mitochondrial DNA disease [7] although isolated cardiomyopathy has been reported in rare mtDNA mutations [26]. Cohort studies have shown that hypertrophic cardiomyopathy and pre-excitation syndrome are prevalent in $\mathrm{m} .3243 \mathrm{~A}>\mathrm{G}[37,45]$ and $\mathrm{m} .8344 \mathrm{~A}>\mathrm{G}[13$, 44] mutations, whereas conduction defect necessitating pacemaker is associated with single, large scale deletion 
particularly among those who have Kearns-Sayre syndrome. Currently, there is limited longitudinal data studying the prevalence of cardiac involvement in various nuclear genes in adults [60]. Baseline cardiac assessment with electrocardiogram (ECG) and echocardiogram should be performed in all patients and cardiac magnetic resonance in selected cases. Subsequent cardiac surveillance should be tailored according to the initial findings but the recommended interval is every 12 to 24 months $[22,55]$.

\section{Diabetes mellitus}

Diabetes mellitus is common in patients with m.3243A $>\mathrm{G}$ and single, large scale mtDNA deletions [70]. Metformin is best avoided because of the theoretical risk of lactic acidosis. Treatment of mitochondrial diabetes is otherwise similar to the usual form of diabetes although it appears that it is associated with a more rapid progression to insulin therapy [93].

\section{Ptosis}

A proportion of patients with CPEO develop significant ptosis that obscures visual field. Corrective ptosis surgery such as frontalis sling operation improves the functional and cosmetic outcome in selected patients [3].

\section{Deafness}

Young onset, bilateral sensori-neural deafness is prevalent in mitochondrial disease. The quality of life of many patients can simply be improved with digital hearing aid and cochlear implant can be reserved for those with severe hearing loss $[36,81]$.

\section{Genetic counselling and reproductive options}

Similarly to other genetic disorders, screening for family members at risk and offering genetic counselling is essential in mitochondrial disease. For patients with nuclear gene disorders, genetic counselling and reproductive options are identical to other nuclear defects. For women with mtDNA mutations genetic counselling is a challenging area. Patients should be reassured if they harbour sporadic mutation, such as single, large scale mtDNA deletion, because risks of transmission are low. For mtDNA point mutations, accurate elucidation of the risk of transmission and prediction of disease status is extremely challenging due to the genetic bottleneck effect and uneven tissue segregation associated with some point mutations. It is estimated that there are approximately 152 births per year in the UK of children who carry potentially pathogenic mitochondrial DNA mutations [27]. In view of the complexity of mtDNA genetics, referral of childbearing age female patients to specialist centres for discussion of reproductive options is recommended. The available options are chorionic villous sampling (CVS), amniocentesis [52] and preimplantation genetic diagnosis (PGD) [68, 87]. CVS and amniocentensis are performed at different stages of pregnancy, 10-12 and 14-20 weeks, respectively. PGD is an IVF procedure that involves embryo biopsy and the selection of embryos with the lowest mutation load. However, PGD will not benefit carriers with homoplasmic mtDNA mutation.

Mitochondrial donation, either pronuclear transfer [18] or metaphase II spindle transfer [82], is emerging as a potential reproductive option to prevent the transmission of mtDNA mutations. In the UK after many years of debate and scientific scrutiny, Mitochondrial Donation Regulations, were passed by both Houses of Parliament, making mitochondrial donation legal for the first time in the UK. The Human Fertilisation and Embryology Authority will now develop a licencing framework through which applications can be considered on a case by case basis.

\section{Conclusions}

Over recent years there have been important advances in mitochondrial disease, particularly in terms of diagnosis and reproductive options available. The role of the clinician remains crucial since a high index of clinical suspicion and prompt recognition of complications remain essential to make an earlier diagnosis and instigate a better management. Currently, the management of mitochondrial disease is largely supportive; however, with the improved understanding of disease mechanisms, ongoing treatment trials and discovery of new therapeutic agents should give hope for patients with mitochondrial disease.

Acknowledgments We would like to thank Charlotte Alston, clinical scientist, for her input on preparing Table 1.

\section{Compliance with ethical standards}

Funding Work in the authors laboratory is supported by The Wellcome Trust $(074454 / \mathrm{Z} / 04 / \mathrm{Z})$, Newcastle University Centre for Ageing and Vitality [supported by the Biotechnology and Biological Sciences Research Council and Medical Research Council (M501700)], MRC Centre for Neuromuscular Disease, UK NIHR Biomedical Research Centre for Ageing and Age-related disease award to the Newcastle upon Tyne Hospitals NHS Foundation Trust, Lily Foundation and the UK NHS Specialist Commissioners which funds the "Rare Mitochondrial Disorders of Adults and Children" Clinical Service in Newcastle upon Tyne. This work also received infrastructure support from the Newcastle NIHR Biomedical Research Centre, Newcastle and North Tyneside Comprehensive Local Research Network. 
Conflicts of interest On behalf of all authors, the corresponding author states that there is no conflict of interest.

Open Access This article is distributed under the terms of the Creative Commons Attribution 4.0 International License (http://crea tivecommons.org/licenses/by/4.0/), which permits unrestricted use, distribution, and reproduction in any medium, provided you give appropriate credit to the original author(s) and the source, provide a link to the Creative Commons license, and indicate if changes were made.

\section{References}

1. Online Mendelian Inheritance in Man, OMIM ${ }^{\circledR}$. McKusickNathans Institute of Genetic Medicine, Johns Hopkins University (Baltimore, MD). http://omim.org/. Accessed 18 Jun 2015

2. Ahmad KE, Davis RL, Sue CM (2015) A novel OPA1 mutation causing variable age of onset autosomal dominant optic atrophy plus in an Australian family. J Neurol, pp 1-6

3. Ahn J, Kim NJ, Choung HK, Hwang SW, Sung M, Lee MJ, Khwarg SI (2008) Frontalis sling operation using silicone rod for the correction of ptosis in chronic progressive external ophthalmoplegia. Br J Ophthalmol 92:1685-1688

4. Alston CL, Schaefer AM, Raman P, Solaroli N, Krishnan KJ, Blakely EL, He L, Craig K, Roberts M, Vyas A, Nixon J, Horvath R, Turnbull DM, Karlsson A, Gorman GS, Taylor RW (2013) Late-onset respiratory failure due to TK2 mutations causing multiple mtDNA deletions. Neurology 81:2051-2053

5. Angelini C, Bello L, Spinazzi M, Ferrati C (2009) Mitochondrial disorders of the nuclear genome. Acta Myologica Myopathies Cardiomyopathies 28:16-23

6. Aurangzeb S, Vale T, Tofaris G, Poulton J, Turner MR (2014) Mitochondrial encephalomyopathy with lactic acidosis and stroke-like episodes (MELAS) in the older adult. Pract Neurol $14: 432-436$

7. Bates MG, Bourke JP, Giordano C, d'Amati G, Turnbull DM, Taylor RW (2012) Cardiac involvement in mitochondrial DNA disease: clinical spectrum, diagnosis, and management. Eur Heart J 33:3023-3033

8. Bernier FP, Boneh A, Dennett X, Chow CW, Cleary MA, Thorburn DR (2002) Diagnostic criteria for respiratory chain disorders in adults and children. Neurology 59:1406-1411

9. Betts J, Barron MJ, Needham SJ, Schaefer AM, Taylor RW, Turnbull DM (2008) Gastrointestinal tract involvement associated with the $3243 \mathrm{~A}>\mathrm{G}$ mitochondrial DNA mutation. Neurology 70:1290-1292

10. Bindoff LA, Engelsen BA (2012) Mitochondrial diseases and epilepsy. Epilepsia 53(Suppl 4):92-97

11. Bitner-Glindzicz M, Pembrey M, Duncan A, Heron J, Ring SM, Hall A, Rahman S (2009) Prevalence of mitochondrial $1555 \mathrm{~A} \rightarrow \mathrm{G}$ mutation in European children. $\mathrm{N}$ Engl $\mathrm{J}$ Med 360:640-642

12. Carelli V, Musumeci O, Caporali L, Zanna C, La Morgia C, Del Dotto V, Porcelli AM, Rugolo M, Valentino ML, Iommarini L, Maresca A, Barboni P, Carbonelli M, Trombetta C, Valente EM, Patergnani S, Giorgi C, Pinton P, Rizzo G, Tonon C, Lodi R, Avoni P, Liguori R, Baruzzi A, Toscano A, Zeviani M (2015) Syndromic parkinsonism and dementia associated with OPA1 missense mutations. Ann Neurol 78:21-38

13. Catteruccia M, Sauchelli D, Della Marca G, Primiano G, Cuccagna C, Bernardo D, Leo M, Camporeale A, Sanna T, Cianfoni A, Servidei S (2015) "Myo-cardiomyopathy" is commonly associated with the A8344G "MERRF" mutation. J Neurol. 263(3):701-710
14. Cheldi A, Ronchi D, Bordoni A, Bordo B, Lanfranconi S, Bellotti MG, Corti S, Lucchini V, Sciacco M, Moggio M, Baron P, Comi GP, Colombo A, Bersano A, on behalf of Lombardia Gc (2013) POLG1 mutations and stroke like episodes: a distinct clinical entity rather than an atypical MELAS syndrome. BMC Neurology $13: 8$

15. Chinnery PF, DiMauro S, Shanske S, Schon EA, Zeviani M, Mariotti C, Carrara F, Lombes A, Laforet P, Ogier H, Jaksch M, Lochmüller H, Horvath R, Deschauer M, Thorburn DR, Bindoff LA, Poulton J, Taylor RW, Matthews JNS, Turnbull DM (2004) Risk of developing a mitochondrial DNA deletion disorder. Lancet 364:592-596

16. Chinnery PF, Hudson G (2013) Mitochondrial genetics. Br Med Bull 106:135-159

17. Chiyonobu T, Noda R, Yoshida M, Fujiki A, Ishii R, Nukina S, Fujita K, Goto Y, Morimoto M (2008) Intestinal pseudo-obstruction in a patient with mitochondrial myopathy, encephalopathy, lactic acidosis, and stroke-like episodes (MELAS) associated with phenytoin therapy. Brain Dev 30:430-433

18. Craven L, Tuppen HA, Greggains GD, Harbottle SJ, Murphy JL, Cree LM, Murdoch AP, Chinnery PF, Taylor RW, Lightowlers RN, Herbert M, Turnbull DM (2010) Pronuclear transfer in human embryos to prevent transmission of mitochondrial DNA disease. Nature 465:82-85

19. Deschauer M, Tennant S, Rokicka A, He L, Kraya T, Turnbull DM, Zierz S, Taylor RW (2007) MELAS associated with mutations in the POLG1 gene. Neurology 68:1741-1742

20. El-Hattab AW, Scaglia F (2013) Mitochondrial DNA depletion syndromes: review and updates of genetic basis, manifestations, and therapeutic options. Neurotherapeutics 10:186-198

21. Elliott HR, Samuels DC, Eden JA, Relton CL, Chinnery PF (2008) Pathogenic mitochondrial DNA mutations are common in the general population. Am J Hum Genet 83:254-260

22. Elliott PM, Anastasakis A, Borger MA, Borggrefe M, Cecchi F, Charron P, Hagege AA, Lafont A, Limongelli G, Mahrholdt H, McKenna WJ, Mogensen J, Nihoyannopoulos P, Nistri S, Pieper PG, Pieske B, Rapezzi C, Rutten FH, Tillmanns C, Watkins H (2014) 2014 ESC Guidelines on diagnosis and management of hypertrophic cardiomyopathy: the task force for the diagnosis and management of hypertrophic cardiomyopathy of the European Society of Cardiology (ESC). Eur Heart J 35:2733-2779

23. Emmanuele V, Lopez LC, Berardo A, Naini A, Tadesse S, Wen B, D'Agostino E, Solomon M, DiMauro S, Quinzii C, Hirano M (2012) Heterogeneity of coenzyme Q10 deficiency: patient study and literature review. Arch Neurol 69:978-983

24. Engelsen BA, Tzoulis C, Karlsen B, Lillebø A, Lægreid LM, Aasly J, Zeviani M, Bindoff LA (2008) POLG1 mutations cause a syndromic epilepsy with occipital lobe predilection. Brain 131:818-828

25. Garone C, Tadesse S, Hirano M (2011) Clinical and genetic spectrum of mitochondrial neurogastrointestinal encephalomyopathy. Brain 134:3326-3332

26. Giordano C, Perli E, Orlandi M, Pisano A, Tuppen HA, He L, Ierino R, Petruzziello L, Terzi A, Autore C, Petrozza V, Gallo P, Taylor RW, d'Amati G (2013) Cardiomyopathies due to homoplasmic mitochondrial tRNA mutations: morphologic and molecular features. Hum Pathol 44:1262-1270

27. Gorman GS, Grady JP, Ng Y, Schaefer AM, McNally RJ, Chinnery PF, Yu-Wai-Man P, Herbert M, Taylor RW, McFarland R, Turnbull DM (2015) Mitochondrial donation-how many women could benefit? N Engl J Med 372:885-887

28. Gorman GS, Schaefer AM, Ng Y, Gomez N, Blakely EL, Alston CL, Feeney C, Horvath R, Yu-Wai-Man P, Chinnery PF, Taylor RW, Turnbull DM, McFarland R (2015) Prevalence of nuclear 
and mitochondrial DNA mutations related to adult mitochondrial disease. Ann Neurol 77(5):753-759

29. Hakonen AH, Davidzon G, Salemi R, Bindoff LA, Van Goethem G, Dimauro S, Thorburn DR, Suomalainen A (2007) Abundance of the POLG disease mutations in Europe, Australia, New Zealand, and the United States explained by single ancient European founders. Eur J Hum Genet 15:779-783

30. Hasselmann O, Blau N, Ramaekers VT, Quadros EV, Sequeira JM, Weissert M (2010) Cerebral folate deficiency and CNS inflammatory markers in Alpers disease. Mol Genet Metab 99:58-61

31. Hirano M, Ricci E, Koenigsberger R, Defendini R, Pavlakis SG, DeVivo DC, DiMauro S, Rowland LP (1992) MELAS: an original case and clinical criteria for diagnosis. Neuromusc Disord 2:125-135

32. Horga A, Pitceathly RD, Blake JC, Woodward CE, Zapater P, Fratter C, Mudanohwo EE, Plant GT, Houlden H, Sweeney MG, Hanna MG, Reilly MM (2014) Peripheral neuropathy predicts nuclear gene defect in patients with mitochondrial ophthalmoplegia. Brain 137:3200-3212

33. Horvath R, Kemp JP, Tuppen HA, Hudson G, Oldfors A, Marie SK, Moslemi AR, Servidei S, Holme E, Shanske S, Kollberg G, Jayakar P, Pyle A, Marks HM, Holinski-Feder E, Scavina M, Walter MC, Coku J, Gunther-Scholz A, Smith PM, McFarland R, Chrzanowska-Lightowlers ZM, Lightowlers RN, Hirano M, Lochmuller H, Taylor RW, Chinnery PF, Tulinius M, DiMauro S (2009) Molecular basis of infantile reversible cytochrome c oxidase deficiency myopathy. Brain 132:3165-3174

34. Joshi CN, Greenberg CR, Mhanni AA, Salman MS (2009) Ketogenic diet in Alpers-Huttenlocher syndrome. Pediatr Neurol 40:314-316

35. Jung I, Park SH, Kim DW (2015) Mitochondrial encephalopathy, lactic acidosis, and stroke-like episode syndrome presenting with prolonged visual aura. J Clin Neurol (Seoul, Korea) 11:104-105

36. Karkos PD, Anari S, Johnson IJ (2005) Cochlear implantation in patients with MELAS syndrome. Eur Arch oto-rhino-Laryngol 262:322-324

37. Kaufmann P, Engelstad K, Wei Y, Kulikova R, Oskoui M, Sproule DM, Battista V, Koenigsberger DY, Pascual JM, Shanske S, Sano M, Mao X, Hirano M, Shungu DC, Dimauro S, De Vivo DC (2011) Natural history of MELAS associated with mitochondrial DNA m.3243A >G genotype. Neurology 77:1965-1971

38. Klopstock T, Yu-Wai-Man P, Dimitriadis K, Rouleau J, Heck S, Bailie M, Atawan A, Chattopadhyay S, Schubert M, Garip A, Kernt M, Petraki D, Rummey C, Leinonen M, Metz G, Griffiths PG, Meier T, Chinnery PF (2011) A randomized placebo-controlled trial of idebenone in Leber's hereditary optic neuropathy. Brain 134:2677-2686

39. Koga Y, Akita Y, Nishioka J, Yatsuga S, Povalko N, Tanabe Y, Fujimoto S, Matsuishi T (2005) L-arginine improves the symptoms of strokelike episodes in MELAS. Neurology 64:710-712

40. Koopman WJH, Willems PHGM, Smeitink JAM (2012) Monogenic mitochondrial disorders. N Engl J Med 366:1132-1141

41. La Morgia C, Achilli A, Iommarini L, Barboni P, Pala M, Olivieri A, Zanna C, Vidoni S, Tonon C, Lodi R, Vetrugno R, Mostacci B, Liguori R, Carroccia R, Montagna P, Rugolo M, Torroni A, Carelli V (2008) Rare mtDNA variants in Leber hereditary optic neuropathy families with recurrence of myoclonus. Neurology 70:762-770

42. Lax NZ, Whittaker RG, Hepplewhite PD, Reeve AK, Blakely EL, Jaros E, Ince PG, Taylor RW, Fawcett PR, Turnbull DM (2012) Sensory neuronopathy in patients harbouring recessive polymerase mutations. Brain 135:62-71

43. Man PYW, Griffiths PG, Brown DT, Howell N, Turnbull DM, Chinnery PF (2003) The epidemiology of Leber hereditary optic neuropathy in the North East of England. Am J Hum Genet 72:333-339

44. Mancuso M, Orsucci D, Angelini C, Bertini E, Carelli V, Comi GP, Minetti C, Moggio M, Mongini T, Servidei S, Tonin P, Toscano A, Uziel G, Bruno C, Caldarazzo Ienco E, Filosto M, Lamperti C, Martinelli D, Moroni I, Musumeci O, Pegoraro E, Ronchi D, Santorelli FM, Sauchelli D, Scarpelli M, Sciacco M, Spinazzi M, Valentino ML, Vercelli L, Zeviani M, Siciliano G (2013) Phenotypic heterogeneity of the 8344A $>\mathrm{G}$ mtDNA "MERRF" mutation. Neurology 80:2049-2054

45. Mancuso M, Orsucci D, Angelini C, Bertini E, Carelli V, Comi G, Donati A, Minetti C, Moggio M, Mongini T, Servidei S, Tonin P, Toscano A, Uziel G, Bruno C, Ienco E, Filosto M, Lamperti C, Catteruccia M, Moroni I, Musumeci O, Pegoraro E, Ronchi D, Santorelli F, Sauchelli D, Scarpelli M, Sciacco M, Valentino M, Vercelli L, Zeviani M, Siciliano G (2014) The m.3243A $>$ G mitochondrial DNA mutation and related phenotypes. A matter of gender? J Neurol 261:504-510

46. Martikainen MH, Paivarinta M, Jaaskelainen S, Majamaa K (2012) Successful treatment of POLG-related mitochondrial epilepsy with antiepileptic drugs and low glycaemic index diet. Epileptic Disord 14:438-441

47. Martinelli D, Catteruccia M, Piemonte F, Pastore A, Tozzi G, Dionisi-Vici C, Pontrelli G, Corsetti T, Livadiotti S, Kheifets V, Hinman A, Shrader WD, Thoolen M, Klein MB, Bertini E, Miller $G$ (2012) EPI-743 reverses the progression of the pediatric mitochondrial disease-genetically defined Leigh Syndrome. Mol Genet Metab 107:383-388

48. McFarland R, Chinnery PF, Blakely EL, Schaefer AM, Morris AA, Foster SM, Tuppen HA, Ramesh V, Dorman PJ, Turnbull DM, Taylor RW (2007) Homoplasmy, heteroplasmy, and mitochondrial dystonia. Neurology 69:911-916

49. McFarland R, Taylor RW, Turnbull DM (2010) A neurological perspective on mitochondrial disease. Lancet Neurol 9:829-840

50. Meisinger C, Sickmann A, Pfanner N (2008) The mitochondrial proteome: from inventory to function. Cell 134:22-24

51. Mokranjac D, Neupert W (2005) Protein import into mitochondria. Biochem Soc Trans 33:1019-1023

52. Nesbitt V, Alston CL, Blakely EL, Fratter C, Feeney CL, Poulton J, Brown GK, Turnbull DM, Taylor RW, McFarland R (2014) A national perspective on prenatal testing for mitochondrial disease. Eur J Hum Genet 22:1255-1259

53. Nesbitt V, Morrison PJ, Crushell E, Donnelly DE, Alston CL, He L, McFarland R, Taylor RW (2012) The clinical spectrum of the $\mathrm{m} .10191 \mathrm{~T}>\mathrm{C}$ mutation in complex I-deficient Leigh syndrome. Dev Med Child Neurol 54:500-506

54. Nesbitt V, Pitceathly RDS, Turnbull DM, Taylor RW, Sweeney MG, Mudanohwo EE, Rahman S, Hanna MG, McFarland R (2013) The UK MRC Mitochondrial Disease Patient Cohort Study: clinical phenotypes associated with the m.3243A $>$ G mutation-implications for diagnosis and management. J Neurol Neurosurg Psychiatry 84:936-938

55. Ng YS, Grady JP, Lax NZ, Bourke JP, Alston CL, Hardy SA, Falkous G, Schaefer AG, Radunovic A, Mohiddin SA, Ralph M, Alhakim A, Taylor RW, McFarland R, Turnbull DM, Gorman GS (2015) Sudden adult death syndrome in m.3243A $>$ G-related mitochondrial disease: an unrecognized clinical entity in young, asymptomatic adults. Eur Heart J. doi:10.1093/eurheartj/ehv306

56. Noack R, Frede S, Albrecht P, Henke N, Pfeiffer A, Knoll K, Dehmel T, Meyer Zu, Horste G, Stettner M, Kieseier BC, Summer H, Golz S, Kochanski A, Wiedau-Pazos M, Arnold S, Lewerenz J, Methner A (2012) Charcot-Marie-Tooth disease CMT4A: GDAP1 increases cellular glutathione and the mitochondrial membrane potential. Hum Mol Genet 21:150-162 
57. Pfeffer G, Burke A, Yu-Wai-Man P, Compston DA, Chinnery PF (2013) Clinical features of MS associated with Leber hereditary optic neuropathy mtDNA mutations. Neurology 81:2073-2081

58. Pfeffer G, Gorman GS, Griffin H, Kurzawa-Akanbi M, Blakely EL, Wilson I, Sitarz K, Moore D, Murphy JL, Alston CL, Pyle A, Coxhead J, Payne B, Gorrie GH, Longman C, Hadjivassiliou M, McConville J, Dick D, Imam I, Hilton D, Norwood F, Baker MR, Jaiser SR, Yu-Wai-Man P, Farrell M, McCarthy A, Lynch T, McFarland R, Schaefer AM, Turnbull DM, Horvath R, Taylor RW, Chinnery PF (2014) Mutations in the SPG7 gene cause chronic progressive external ophthalmoplegia through disordered mitochondrial DNA maintenance. Brain 137:1323-1336

59. Pfeffer G, Majamaa K, Turnbull DM, Thorburn D, Chinnery PF (2012) Treatment for mitochondrial disorders. Cochrane Database syst rev (4):Cd004426. doi:10.1002/14651858.CD004426. pub3

60. Pfeffer G, Mezei MM (2012) Cardiac screening investigations in adult-onset progressive external ophthalmoplegia patients. Muscle Nerve 46:593-596

61. Pfeffer G, Pyle A, Griffin H, Miller J, Wilson V, Turnbull L, Fawcett K, Sims D, Eglon G, Hadjivassiliou M, Horvath R, Nemeth A, Chinnery PF (2015) SPG7 mutations are a common cause of undiagnosed ataxia. Neurology 84:1174-1176

62. Phoenix C, Schaefer AM, Elson JL, Morava E, Bugiani M, Uziel G, Smeitink JA, Turnbull DM, McFarland R (2006) A scale to monitor progression and treatment of mitochondrial disease in children. Neuromuscul Disord 16:814-820

63. Prasun P, Koeberl DD (2014) Mitochondrial neurogastrointestinal encephalomyopathy (MNGIE)-like phenotype in a patient with a novel heterozygous POLG mutation. J Neurol 261:1818-1819

64. Prüss H, Holtkamp M (2008) Ketamine successfully terminates malignant status epilepticus. Epilepsy Res 82:219-222

65. Rahman S, Poulton J, Marchington D, Suomalainen A (2001) Decrease of $3243 \mathrm{~A} \rightarrow \mathrm{G}$ mtDNA mutation from blood in MELAS syndrome: a longitudinal study. Am J Hum Genet 68:238-240

66. Rance G, Kearns LS, Tan J, Gravina A, Rosenfeld L, Henley L, Carew P, Graydon K, O'Hare F, Mackey DA (2012) Auditory function in individuals within Leber's hereditary optic neuropathy pedigrees. J Neurol 259:542-550

67. Sadun AA, Chicani CF, Ross-Cisneros FN, Barboni P, Thoolen M, Shrader WD, Kubis K, Carelli V, Miller G (2012) Effect of EPI-743 on the clinical course of the mitochondrial disease Leber hereditary optic neuropathy. Arch Neurol 69:331-338

68. Sallevelt SC, Dreesen JC, Drusedau M, Spierts S, Coonen E, van Tienen FH, van Golde RJ, de Coo IF, Geraedts JP, de DieSmulders CE, Smeets HJ (2013) Preimplantation genetic diagnosis in mitochondrial DNA disorders: challenge and success. J Med Genet 50:125-132

69. Schaefer AM, Phoenix C, Elson JL, McFarland R, Chinnery PF, Turnbull DM (2006) Mitochondrial disease in adults: a scale to monitor progression and treatment. Neurology 66:1932-1934

70. Schaefer AM, Walker M, Turnbull DM, Taylor RW (2013) Endocrine disorders in mitochondrial disease. Mol Cell Endocrinol 379:2-11

71. Schapira AHV (2012) Mitochondrial diseases. Lancet 379:1825-1834

72. Schon EA, DiMauro S, Hirano M (2012) Human mitochondrial DNA: roles of inherited and somatic mutations. Nat Rev Genet 13:878-890

73. Schwabe MJ, Dobyns WB, Burke B, Armstrong DL (1997) Valproate-induced liver failure in one of two siblings with Alpers disease. Pediatr Neurol 16:337-343

74. Sekino Y, Inamori M, Yamada E, Ohkubo H, Sakai E, Higurashi T, Iida H, Hosono K, Endo H, Nonaka T, Takahashi H, Koide T, Abe Y, Gotoh E, Koyano S, Kuroiwa Y, Maeda S, Nakajima A
(2012) Characteristics of intestinal pseudo-obstruction in patients with mitochondrial diseases. World $\mathrm{J}$ Gastroenterol 18:4557-4562

75. Sicurelli F, Carluccio MA, Toraldo F, Tozzi M, Bucalossi A, Lenoci M, Jacomelli G, Micheli V, Cardaioli E, Mondelli M, Federico A, Marotta G, Dotti MT (2012) Clinical and biochemical improvement following HSCT in a patient with MNGIE: 1-year follow-up. J Neurol 259:1985-1987

76. Smits P, Smeitink J, van den Heuvel L (2010) Mitochondrial translation and beyond: processes implicated in combined oxidative phosphorylation deficiencies. J Biomed Biotechnol 2010:737385

77. Sommerville EW, Chinnery PF, Grainne GS, Taylor RW (2014) Adult-onset mendelian PEO associated with mitochondrial disease. J Neuromuscul Dis 1:119-133

78. Steenweg ME, Ghezzi D, Haack T, Abbink TE, Martinelli D, van Berkel CG, Bley A, Diogo L, Grillo E, Te Water Naude J, Strom TM, Bertini E, Prokisch H, van der Knaap MS, Zeviani M (2012) Leukoencephalopathy with thalamus and brainstem involvement and high lactate 'LTBL' caused by EARS2 mutations. Brain 135:1387-1394

79. Steriade C, Andrade DM, Faghfoury H, Tarnopolsky MA, Tai P (2014) Mitochondrial encephalopathy with lactic acidosis and stroke-like episodes (MELAS) may respond to adjunctive ketogenic diet. Pediatr Neurol 50:498-502

80. Stewart JD, Horvath R, Baruffini E, Ferrero I, Bulst S, Watkins PB, Fontana RJ, Day CP, Chinnery PF (2010) Polymerase $\gamma$ Gene POLG determines the risk of sodium valproate-induced liver toxicity. Hepatology (Baltimore, MD) 52:1791-1796

81. Sue CM, Lipsett LJ, Crimmins DS, Tsang CS, Boyages SC, Presgrave CM, Gibson WP, Byrne E, Morris JG (1998) Cochlear origin of hearing loss in MELAS syndrome. Ann Neurol 43:350-359

82. Tachibana M, Sparman M, Sritanaudomchai H, Ma H, Clepper L, Woodward J, Li Y, Ramsey C, Kolotushkina O, Mitalipov S (2009) Mitochondrial gene replacement in primate offspring and embryonic stem cells. Nature 461:367-372

83. Tang S, Dimberg EL, Milone M, Wong LJ (2012) Mitochondrial neurogastrointestinal encephalomyopathy (MNGIE)-like phenotype: an expanded clinical spectrum of POLG1 mutations. J Neurol 259:862-868

84. Taylor RW, Pyle A, Griffin H, Blakely EL, Duff J, He L, Smertenko T, Alston CL, Neeve VC, Best A, Yarham JW, Kirschner J, Schara U, Talim B, Topaloglu H, Baric I, HolinskiFeder E, Abicht A, Czermin B, Kleinle S, Morris AA, Vassallo G, Gorman GS, Ramesh V, Turnbull DM, Santibanez-Koref M, McFarland R, Horvath R, Chinnery PF (2014) Use of wholeexome sequencing to determine the genetic basis of multiple mitochondrial respiratory chain complex deficiencies. JAMA 312:68-77

85. Taylor RW, Schaefer AM, Barron MJ, McFarland R, Turnbull DM (2004) The diagnosis of mitochondrial muscle disease. Neuromuscul Disord 14:237-245

86. Taylor RW, Turnbull DM (2005) Mitochondrial DNA mutations in human disease. Nat Rev Genet 6:389-402

87. Treff NR, Campos J, Tao X, Levy B, Ferry KM, Scott RT Jr (2012) Blastocyst preimplantation genetic diagnosis (PGD) of a mitochondrial DNA disorder. Fertil Steril 98:1236-1240

88. Tucker EJ, Compton AG, Thorburn DR (2010) Recent advances in the genetics of mitochondrial encephalopathies. Curr Neurol Neurosci Rep 10:277-285

89. van Berge L, Hamilton EM, Linnankivi T, Uziel G, Steenweg ME, Isohanni P, Wolf NI, Krageloh-Mann I, Brautaset NJ, Andrews PI, de Jong BA, al Ghamdi M, van Wieringen WN, Tannous BA, Hulleman E, Wurdinger T, van Berkel CG, Polder E, Abbink TE, Struys EA, Scheper GC, van der Knaap MS (2014) 
Leukoencephalopathy with brainstem and spinal cord involvement and lactate elevation: clinical and genetic characterization and target for therapy. Brain 137:1019-1029

90. Verny C, Amati-Bonneau P, Letournel F, Person B, Dib N, Malinge MC, Slama A, Le Maréchal C, Ferec C, Procaccio V, Reynier P, Bonneau D (2008) Mitochondrial DNA A3243G mutation involved in familial diabetes, chronic intestinal pseudoobstruction and recurrent pancreatitis. Diabetes Metab 34:620-626

91. Visser NA, Braun KPJ, Leijten FSS, Van Nieuwenhuizen O, Wokke JHJ, Van Den Bergh WM (2011) Magnesium treatment for patients with refractory status epilepticus due to POLG1mutations. J Neurol 258:218-222

92. Vrettou CS, Zervakis D, Priovolos A, Koskina S, Tsamouri M, Routsi C (2013) MELAS syndrome diagnosed in ICU in a 56-year-old patient presenting with status epilepticus. Intensiv Care Med 39:1148-1149

93. Whittaker RG, Schaefer AM, McFarland R, Taylor RW, Walker M, Turnbull DM (2007) Prevalence and progression of diabetes in mitochondrial disease. Diabetologia 50:2085-2089

94. Ylikallio E, Suomalainen A (2012) Mechanisms of mitochondrial diseases. Ann Med 44:41-59
95. Yu-Wai-Man P, Griffiths PG, Gorman GS, Lourenco CM, Wright AF, Auer-Grumbach M, Toscano A, Musumeci O, Valentino ML, Caporali L, Lamperti C, Tallaksen CM, Duffey P, Miller J, Whittaker RG, Baker MR, Jackson MJ, Clarke MP, Dhillon B, Czermin B, Stewart JD, Hudson G, Reynier P, Bonneau D, Marques W, Lenaers G, McFarland R, Taylor RW, Turnbull DM, Votruba M, Zeviani M, Carelli V, Bindoff LA, Horvath R, Amati-Bonneau P, Chinnery PF (2010) Multi-system neurological disease is common in patients with OPA1 mutations. Brain 133:771-786

96. Zimon M, Baets J, Fabrizi GM, Jaakkola E, Kabzinska D, Pilch J, Schindler AB, Cornblath DR, Fischbeck KH, Auer-Grumbach M, Guelly C, Huber N, De Vriendt E, Timmerman V, Suter U, Hausmanowa-Petrusewicz I, Niemann A, Kochanski A, De Jonghe P, Jordanova A (2011) Dominant GDAP1 mutations cause predominantly mild CMT phenotypes. Neurology 77:540-548

97. Zoccolella S, Petruzzella V, Prascina F, Artuso L, Pacillo F, Dell'Aglio R, Avolio C, Delle Noci N, Attimonelli M, Specchio LM (2010) Late-onset Leber hereditary optic neuropathy mimicking Susac's syndrome. J Neurol 257:1999-2003 